\title{
The Effect of Parents' Attention, Physical Fitness and Students' Motivation in Learning Process toward Students' Achievement of Sport Study
}

\author{
Yuhanda Gustian*, Kamal Firdaus \\ Sport Education Program \\ Faculty of Sport Science \\ Universitas Negeri Padang \\ Padang, Indonesia \\ kamalfirdaus@ fik.unp.ac.id
}

\begin{abstract}
This research had an aim to disclose an influence of exogenous variables to an endogenous variable directly, casually, simultaneously. This research used a quantitative method with the Path Analysis approach, which involved 38 students. Data were collected using questionnaires to measure parent's attention and students' motivation in the learning process, TKJI test to get the data of physical fitness from students in sixth semester 2018/2019. The result of this research and data analysis showed: (1) Parents' attention influenced the students directly and significantly toward students' sport. (2) Physical fitness influenced the students directly and significantly toward students' sport achievement. (3) Students' motivation in the learning process influenced the students directly and significantly toward students' sport achievement. (4) Parents' attention influenced the students indirectly toward students' sport achievement. (5) Physical fitness influenced the students indirectly toward students' sport achievement through students' motivation in the learning process. (6) Parents' attention, Physical fitness, and Student's motivation in learning process influenced the students simultaneously toward students' sport achievement
\end{abstract}

Keywords-Parents' Attention, Physical Fitness, Motivation, learning process

\section{INTRODUCTION}

"States that "student learning outcomes are essentially changes in behavior and as feedback in an effort to improve the teaching and learning process. Learning outcomes obtained by students are inseparable from the various factors that influence it" [1]. Such factors originating from the inside (intrinsic) and factors originating from outside the students themselves (external). In line with this "explains the factors that influence the following learning: "1) Internal factors consist of: a) Internal factors consist of: Physical factors, psychological factors, 2) External factors consist of: a) Factors family, b) School factors, c) Community factors "[2].

"Expressed his opinion about the attention of parents, namely the concentration of mental awareness in the form of energy, thoughts and feelings, from parents to their children, transformed in various ways to provide motivation or positive encouragement to their children in an effort to achieve optimal learning results" [3]. From these descriptions it can be concluded the understanding of parental attention, is a parent's awareness in educating, guiding, and caring for their children (both in the form of actions and speech) with great affection so that children can achieve their ideals and life independent.

Viewed in terms of physiology (physiology), "asserted that the freshness of Jasmani is the ability and ability to kill in making adjustments (adaptation) to the physical loading given to it (work) without experiencing significant fatigue" [4]. States that physical fitness is the ability and ability to make adjustments (adaptation) to the physical liberation given to him (from work done daily) without causing excessive fatigue. Regarding the freshness of this physical" [5], "also explains that physical fitness related to health is a person's ability to perform physical tasks that require strength, endurance" [6].

Physical fitness was also discussed by "he emphasized that physical fitness is the ability of the body to perform daily tasks and work hard, without experiencing significant fatigue and remaining energy reserves, still able to enjoy free time and deal with things emergency things that were unexpected before" [7]. [4] said that "physical fitness is a reflection of the ability of the functioning of systems in the body that can an increase in the quality of life in every physical activity". Then also explains that physical fitness is "the ability of a person to be able to do his daily work efficiently without arising from excessive fatigue so that he can still enjoy his free time" [8]. In other words good physical fitness will affect the learning activities of students where students will be more enthusiastic in following the learning.

According to "the general function of physical fitness is "to develop the strength, ability, ability, creative power and endurance of every human being which is useful to enhance work power in development and to defend the nation and state" [9]. The special function for children is for growth and development and to improve learning achievement.

Quoted by "states that "motivation is a change in energy in a person which is characterized by the emergence of" feeling "and preceded by a response to the existence of goals" [10]. Argues that "motivation and learning are two 
things that influence each other" [11]. Learning motivation can arise due to intrinsic factors, in the form of the desire and desire to succeed and the drive for learning needs, hopes for ideals. While the extrinsic factor is the existence of appreciation, a conducive learning environment, and interesting learning activities. Learning motivation is very closely related to the behavior of students at school. Learning motivation can arouse and direct students to learn something new. If educators arouse students' learning motivation, then they will strengthen the responses that have been learned. High learning motivation is reflected in the perseverance that is not easily broken to achieve success despite being confronted by various difficulties.

Motivation is a stimulus that arises from within the individual to then take action. In order for actions or behaviors carried out in accordance with expectations, it is necessary to be motivated to encourage individuals to take the expected actions. According "there are five factors that can influence student learning motivation, namely the teacher, direct instruction, feed back, gifts, and punishment" [12].

\section{RESEARCH METHODOLOGY}

The independent variable (independent variable) is the variable that influences or is the cause of its change or emergence, while the dependent variable (dependent In this study there are 2 main variables: the independent variable (Independent Variable) and the dependent variable (Dependent Variable). According variable) dependent variable) is a variable that is affected or that is due, because of the independent variables. This research was conducted in November2018 and located at SMK N 1 Solok City. The population used in this study were all students of class XI students in SMK N 1 Solok City, totaling 76 students. The sampling technique is done by using simple random sampling technique. So the total number of students chosen to be sampled is 38 people.

The type of instrument used in this study is in the form of a questionnaire, which is the type of questionnaire or questionnaire with a Likert scale. The preparation of the instrument refers to the grid made according to the dependent variable of the study. The development of the instrument is based on variables that are translated in the grid TKJI instruments aged 16-19 years consisting of: 1) Sprint Test (60 meter Sprint). 2) Body Lift Test (Pull Up 60 seconds, hang your elbows to bend for female students). 3) Sitting Lying Test (Sit Up 60 seconds). 4) Vertical Jump Test. 5) Run Away Test (Run 1200 meters for the son and run 1000 meters for the princess). Data analysis technique in this research is descriptive descriptive analysis technique.

\section{RESULTS}

\section{Parental Attention}

Table 1. Data Frequency Distribution of Parents' Attention

\begin{tabular}{|c|c|c|}
\hline $\begin{array}{c}\text { Kelas } \\
\text { Interval }\end{array}$ & $\begin{array}{c}\text { Frekuensi } \\
\text { Absolut }\end{array}$ & $\begin{array}{c}\text { Frekuensi } \\
\text { Relatif (\%) }\end{array}$ \\
\hline $69-82$ & 7 & 18.42 \\
\hline $83-96$ & 16 & 42.11 \\
\hline $97-110$ & 8 & 21.05 \\
\hline
\end{tabular}

\begin{tabular}{|l|l|l|}
\hline $111-124$ & 5 & 13.16 \\
\hline $125-138$ & 2 & 5.26 \\
\hline$\sum$ & 38 & 100.00 \\
\hline
\end{tabular}

For more details can be described as follows;

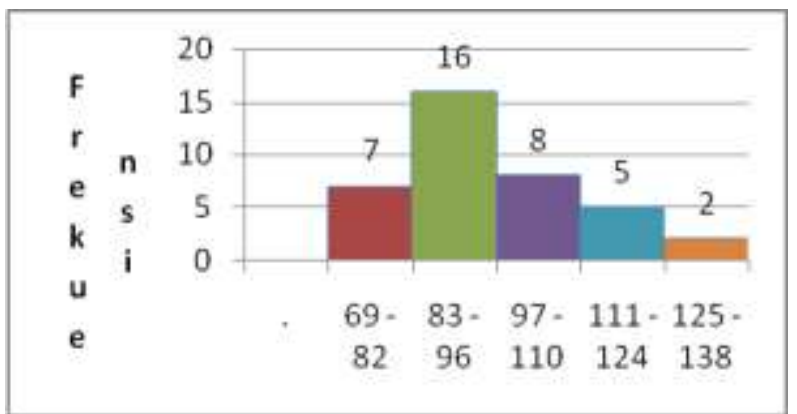

Figure 1. Histogram Data of Parents' Attention Data

Based on the table and histogram above shows the attention of parents of 38 samples in male students of SMK N 1 Solok as many as 7 respondents were in class i4nterval 69-82.16 respondents were in the interval 83-96, 8 respondents were in the interval 97-110, 5 respondents were in the 111-124 interval and 2 respondents were in the 125-138 interval

1. Physical Fitness

Table 2. Frequency Distribution of Physical Fitness Data

\begin{tabular}{|c|c|c|}
\hline $\begin{array}{l}\text { Interval } \\
\text { Class }\end{array}$ & $\begin{array}{l}\text { Frequency } \\
\text { Absolut }\end{array}$ & $\begin{array}{l}\text { Frequency } \\
\text { Relatifve(\%) }\end{array}$ \\
\hline $9-11$ & 1 & 2.63 \\
\hline $12-14$ & 3 & 7.89 \\
\hline $15-17$ & 5 & 13.16 \\
\hline $18-20$ & 25 & 65.79 \\
\hline $21-23$ & 4 & 10.53 \\
\hline$\sum$ & 38 & 100.00 \\
\hline
\end{tabular}

For more details can be described as follows

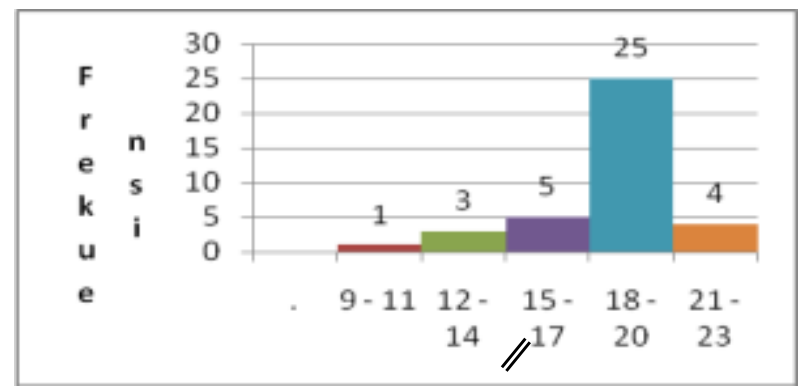

Figure 2. Histogram of Physical Fitness Data

Based on the tables and histograms above, physical fitness from 38 samples in the male students of SMK N 1 Solok is 1 respondent who is in the 9-11 interval class, 3 respondents are in the 12-14 interval, 5 respondents are in the interval 15-17, 25 respondents are in the 18-20 interval and 4 respondents are in the 21-23 interval. 
2. Learning Motivation

Table 3. Frequency Distribution of Learning Motivation Data

\begin{tabular}{|c|c|c|}
\hline $\begin{array}{l}\text { Interval } \\
\text { Class }\end{array}$ & $\begin{array}{c}\text { Freque } \\
\text { ncy } \\
\text { Absolut }\end{array}$ & $\begin{array}{l}\text { Frequency } \\
\text { Relatifve(\%) }\end{array}$ \\
\hline $88-118$ & 3 & 7.89 \\
\hline $119-149$ & 3 & 7.89 \\
\hline $150-180$ & 7 & 18.42 \\
\hline $181-211$ & 22 & 57.89 \\
\hline $212-242$ & 3 & 7.89 \\
\hline$\sum$ & 38 & 100.00 \\
\hline
\end{tabular}

For more details can be described as follows ;

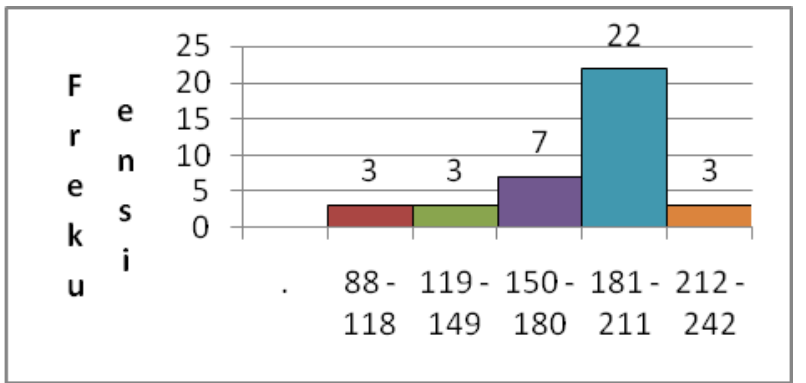

Figure 3. Learning Motivation Data Histogram

Based on the table and histogram above, it can be seen the motivation of learning from 38 samples in the male students of SMK N 1 Solok as many as 3 respondents were in the 88-118 interval class, 3 respondents were in the 119-149 interval, 7 respondents were in the interval 150-180, 22 respondents were in the 181-211 interval and 3 respondents were in the 212-242 interval.

\section{Learning Outcomes}

Table 4. Frequency Distribution of Learning Outcomes Data

\begin{tabular}{|c|c|c|}
\hline Interval Class & $\begin{array}{l}\text { Frequency } \\
\text { Absolut }\end{array}$ & $\begin{array}{l}\text { Frequency } \\
\text { Relatifve(\%) }\end{array}$ \\
\hline $60-64$ & 4 & 10.53 \\
\hline $65-69$ & 5 & 13.16 \\
\hline $70-74$ & 6 & 15.79 \\
\hline $75-79$ & 16 & 42.11 \\
\hline $80-84$ & 7 & 18.42 \\
\hline$\sum$ & 38 & 100.00 \\
\hline
\end{tabular}

For more details can be described as follows ;

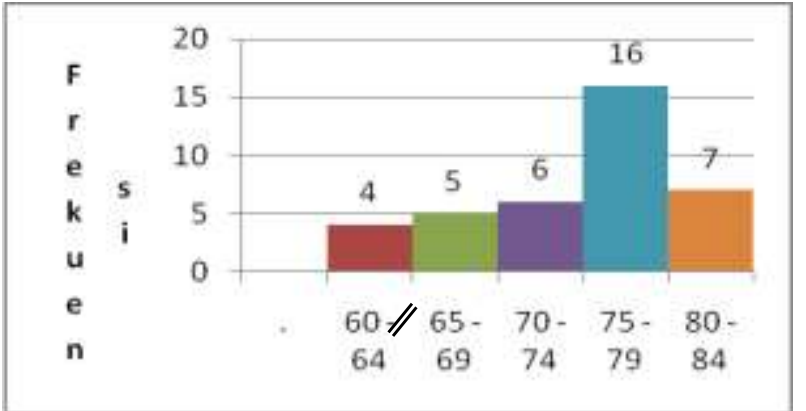

Figure 4. Learning Results Data Histogram

Based on the table and histogram above, it can be seen the learning outcomes of 38 samples in the male students of SMK $\mathrm{N} 1$ Solok as many as 4 respondents were in the class interval $60-64,5$ respondents were in the interval $65-69,6$ respondents were in the interval 70-74, 16 respondents were in the 75-79 interval and 7 respondents were in the 80-84 interval.

\section{DISCUSSION}

1. Direct influence of parents' attention on student learning outcomes at SMK Negeri 1 Solok.

The attention given by parents to their children will greatly affect the learning outcomes that will be achieved by these students. Usually, students who get more attention will get better learning outcomes when compared to students who are less noticed. Students who have caring parents, will always be controlled and given direction for all activities in the school. If the activities carried out are positive, then parents will always provide support and will continue to motivate their children to do other good things, especially in terms of learning. If the activities carried out by their children have led to negative things that can have an impact that is not on the learning outcomes that will be obtained by the child. Call it juvenile delinquency, parents must be able to position themselves so that the child wants to leave things that smell negative and return to do things that are more useful. Especially children in high school and above, because they are very vulnerable to the influence of things that are not good.

2. The direct effect of physical fitness on student learning outcomes at SMK Negeri 1 Solok.

Freshness or physical fitness is the body's ability to perform daily tasks and work actively, without experiencing significant exhaustion, as well as with the remaining energy reserves still able to enjoy leisure time and deal with unexpected things. Viewed in terms of physiology (physiology), Moeloek in Agus "emphasized that physical fitness is the ability and ability of the body to make adjustments (adaptation) to the physical loading given to it (work) without experiencing significant exhaustion" [4].

Students who have good physical fitness will usually look more active and enthusiastic in carrying out various learning activities in school. This is because they have enough energy reserves so that they do not feel tired quickly. Inversely proportional to students who have poor physical fitness. They usually look less enthusiastic in participating in PJOK learning. Because in their minds following this study will consume a lot of energy which will make them tired.

3. The direct effect of learning motivation on student learning outcomes at SMK 1 Solok.

Learning motivation owned by students is one of the factors that also influences the learning outcomes to be achieved by these students. The higher the learning motivation they have, the better the learning outcomes achieved by students, and conversely the lower the learning motivation that is owned by a student, it will be directly proportional to the learning outcomes he gets. Those who have high learning motivation will have a clear picture of the goals to be achieved. This is what causes those who have high learning motivation to get more satisfying learning outcomes.

It can be said that emotional intelligence is a factor that is quite dominant in achieving the results or goals to be 
achieved by students. Based on relevant studies that the authors have described, there is a chapter II of emotional intelligence that students can influence the learning outcomes achieved. Research conducted by Doni shows emotional intelligence has a direct effect on performance, this has relevance to the results of research that the authors do. can be interpreted that emotional intelligence is an element that plays a fairly dominant role in performance and learning outcomes, as well as students in SMK Negeri 1 Solok in achieving goals or learning outcomes.

\section{The influence of parents' attention through learning motivation on student learning outcomes in SMK 1 Solok.}

Parents' attention is the focus of the parent's point of view to their children as indicated by the fulfillment of children's needs which include physical needs, (boards, clothing, food and other facilities related to the needs of children in accordance with the child's mental development including learning, play, and health facilities children), and non-physical needs (outpouring of affection, the opening of communication between children and parents, the formation of a disciplined life attitude in the family, the appreciation for achievement and sanctions for violating rules).

Therefore, parents have an important role as forming characters and patterns of thought and personality of children. This is because parents are the main actors in building a good family, where the family is where the children first get acquainted with values and norms. Although in the family there are no formal curriculum and programs in implementing learning activities, but the nature of learning in the family is very potential and fundamental. Here is the important role of parents in shaping the child's personality.

Through the attention given by parents to a child, especially children who are educated have a significant impact as well. If the parents of a student always pay attention to every need and learning activity that is passed by their child, then it will be able to cause motivation to learn about the child. As we know that learning motivation is also an aspect that also influences the achievement of maximum learning outcomes. The greater attention given by parents to their children will also indirectly be able to improve learning outcomes.

5. There is an influence of physical fitness through learning motivation on the learning outcomes of students at SMK 1 Solok.

Physical fitness is a factor that affects the learning outcomes to be received by students. Students who have good physical fitness will certainly be active in following the learning process. If the students actively participate in learning and obey all instructions given by the teacher, the students will get satisfying learning outcomes. Furthermore, what also influences the learning outcomes to be received by students is learning motivation.

Motivation to learn is the encouragement of students both from within and outside themselves learners to participate in the learning process at school, especially in Physical Education and Health (PJOK) subjects. Students with high learning motivation both motivation that comes from within (intrinsic motivation) and motivation that comes from outside (extrinsic motivation) tend to get satisfying learning outcomes and conversely students who have low learning motivation will get learning outcomes that are less satisfactory.

Based on the description above, it is suspected that there is an influence of physical fitness through learning motivation towards Physical Education learning outcomes obtained by students. Students who have physical fitness and high learning motivation are expected to get satisfying learning outcomes. Vice versa students who have physical fitness and low learning motivation will be difficult to get satisfying learning outcomes. Therefore, it is suspected that there is an indirect effect of physical fitness on Physical Education learning outcomes through students' learning motivation.

6. Effect of parental attention, physical fitness and learning motivation on student learning outcomes at SMK Negeri 1 Solok.

Based on a theoretical study, the conceptual framework that has been presented is followed by several hypotheses proposed in this study of each of the variables of parent's attention, physical fitness and learning motivation towards student learning outcomes at SMK Negeri 1 Solok, learning motivation variables that have the most influence small towards the learning outcomes achieved by students. This clearly proves that each variable has a different effect on the learning outcomes achieved by students at SMK Negeri 1 Solok. The results of this study explain that the learning outcomes achieved by students affected by these three tractors gave a value of $23.43 \%$ and the rest could have been influenced by other factors that the researchers did not discuss in this study. The factors in question are the environment, genetic factors, physical health and much more.

Based on the findings in this study, all exogenous variables in this study have an influence on endogenous variables. It can be seen through the results of the study that if these three exogenous variables are integrated simultaneously (together) then it gives more significant results compared to the direct influence between exogenous variables. Can be interpreted that student learning outcomes can be improved by increasing exogenous variables, as well as learning outcomes at SMK Negeri 1 Solok, if you want to have maximum results

\section{CONCLUSION}

Based on the results of data analysis and discussion described in the previous chapter, the following conclusions can be drawn: 1) There is a direct and significant influence of parents' attention on student learning outcomes in SMK Negeri 1 Solok. 2) There is a significant direct effect on physical fitness on learning outcomes through emotional intelligence in students at SMK Negeri 1 Solok. 3) There is a direct and significant influence of learning motivation on learning outcomes in students at SMK Negeri 1 Solok. 4) There is an indirect effect of parents' attention on learning outcomes through learning motivation of students in SMK Negeri 1 Solok. 5) There is an indirect effect of physical fitness on learning 
outcomes through students' learning motivation at SMK Negeri 1 Solok. 6) There is a significant influence between parents' attention, physical fitness and learning motivation simultaneously on the learning outcomes of students at SMK Negeri 1 Solok

\section{REFERENCES}

[1] Sudjana, Nana, "Dasar-dasar Proses Belajar," Bandung; Sinar Baru. 2010, pp, 56-62.

[2] Slameto, "Belajar \& Faktor-Faktor yang Mempengaruhi," Jakarta: Rineka. Cipta. 2010.

[3] Santoso, "Studi Deskriptif Penelitian Penelitian," Fakultas Psikologi Universitas Dharma. 2010.

[4] Apri.Agus, "Olahraga Kebugaran Jasmani,". Padang; Sukabina Press. 2012 pp, 76-86.

[5] Muhajir, "Pendidikan Jasmani Olahraga dan Kesehatan,” Bandung; Yudistira. 2007.

[6] Rusli,Lutan, "Asas-Asas Pendidikan Jasmani," Jakarta; Direktorat Jenderal Pendidikan Dasar dan Menengah Departemen Pendidikan dan Kebudayaan. 2001.

[7] Wahjoedi, "Landasan Pendidikan Jasmani," Jakarta; PT. Raja Grafindo Persada. 2000
[8] Pekik, Djoko Irianto, "Bugar dan Sehat Dengan Olahraga. Yogyakarta; Andi Offset. 2004

[9] Cholik, Mutohir Toho \& Gusri,. "Perkembangan Motorik Pada Masa Anak-anak," Jakarta; Depdiknas. 2004.

[10] Sardiman, "Interaksi dan Motivasi Belajar Mengajar," Jakarta; PT Raja Grafindo Persada. 2003, pp, 35-40.

[11] Uno, Hamzah B, "Teori motivasi dan Pengukurannya (Analisis di Bidang Pendidikan)," Jakarta; Bumi Aksara. 2008.

[12] Brophy, "Motivasi Belajar Mengajar," Jakarta; Rajawali Pers. 2010, pp, 324-326. 